\title{
Global geographical climate impacts on the spread and death of COVID-19 in Asia and America
}

\author{
Shafaf Ibrahim ${ }^{*}$, Saadi Ahmad Kamaruddin ${ }^{2}$, Mohd Rahmat Mohd Nordin ${ }^{1}$, Anis Amilah Shari ${ }^{1}$, \\ Nurbaity Sabri ${ }^{1}$ and Khyrina Airin Fizah Abu Samah ${ }^{1}$ \\ Faculty of Computer and Mathematical Sciences, Universiti Teknologi MARA, Jasin, Melaka, Malaysia ${ }^{1}$ \\ School of Quantitative Sciences, College of Arts \& Sciences, Universiti Utara Malaysia, 06010 UUM Sintok, Kedah \\ Darul Aman, Malaysia ${ }^{2}$
}

Received: 25-October-2020; Revised: 21-January-2021; Accepted: 26-January-2021

(C)2021 Shafaf Ibrahim et al. This is an open access article distributed under the Creative Commons Attribution (CC BY) License, which permits unrestricted use, distribution, and reproduction in any medium, provided the original work is properly cited.

\begin{abstract}
A viral infection which is named as Coronavirus disease 2019 (COVID-19) is triggered by the Severe Acute Respiratory Syndrome Coronavirus 2 (SARS-CoV-2). To date, almost two million cases and over 100,000 deaths from the disease caused by this virus were reported worldwide. The environmental and meteorological factors are claimed to stimulate the spread of the virus in which the transmissibility in terms of climatic fluctuations increases exponentially with high humidity and low temperature. In an attempt to understand this epidemic, there is a need to investigate the factors that could impact the spread and death of COVID-19. We, therefore, proposed to investigate global geographical climate impacts on the COVID-19 spread and death in Asia and America. The Artificial Neural Network (ANN) is a network that seeks to replicate neuronal functionality in the human brain. It is the preferred instrument for several predictive applications of data mining, due to its strength, versatility, and simplicity. A dataset of COVID-19 cases and deaths revealed from 49 states in America and 41 countries in Asia during April 2020 were tested. Nine covariates were used in the networks which are Cases, Death, High Temperature, Low Temperature, Average Temperature, Population, and Percentage of Cases over Population, Percentage of Death over Population, and Total Cases. Based on the analysis conducted, the global geographic climate is observed to have the least impacts on the COVID-19 spread and death in Asia and America particularly. However, different results could be reflected by different datasets used in the future.
\end{abstract}

\section{Keywords}

Geographical climate, Covid-19, Asia, America, Artificial neural network.

\section{Introduction}

A viral infection which is named as Coronavirus disease 2019 (COVID-19) is triggered by the Severe Acute Respiratory Syndrome Coronavirus 2 (SARSCoV-2) [1]. Presently, there are reportedly almost two million infections and more than 100,000 worldwide deaths from the disease caused by this virus [2]. The medical and research groups are working together to reduce the serious effects of the outbreak. With more than 327000 cases registered, the United States of America reported the highest rise since the beginning of August 2020, in newly reported cases. Meanwhile, the progressive decline in the occurrence of cases and deaths in the area of South East Asia were reported [3].

*Author for correspondence 149
It is therefore important to generate awareness of mechanisms that contribute to the COVID-19 spread and death, its effect on host immunity, and to have a better understanding on how to strengthen our preparedness for any potential transmission of this pandemic outbreak.

Numerous studies have been conducted to examine causes that may influence the spread of COVID-19 [4] in an effort to explain these epidemics. The transmission agent, host, and surroundings are the three factors that affect the communicable diseases epidemiology [5]. Generally, SARS events have been partially related to environmental factors [6]. The air temperature was another environmental factor. In colder environments, the respirational system infections are more frequent and lesser at higher climatic temperatures since they might not be able to endure climate change [7]. In terms of climatic 
variability, the transmissibility of COVID-19 is close to the influenza virus, where it increases exponentially with high humidity and low temperature [8], signifying that climatic variables may have a major effect on viral transmission. The meteorological conditions also tend to affect the spread of the virus [9].

In another note, the Artificial Neural Network (ANN) is a network that seeks to replicate neuronal functionality in the human brain. A neuron can be recognized as a transmitter which interrelates with a specific output when stimulated by a particular input or input array [10]. It is the preferred instrument for several predictive applications of data mining, due to its strength, versatility and simplicity. The predictive neural networks are principally helpful for applications with complex underlying mechanisms, such as wind speed prediction model [11], forecasting of student's success [12], predicting surface settlement [13], global solar radiation prediction [14], and many more. ANN is widely used in predictive applications [15], for instance, the radial basis function (RBF) and multilayer perceptron (MLP) networks, are controlled in a way that the known target variable values is compared to the model-predicted results.

Thus, on the basis that COVID-1919 plays an important role in various climatic conditions, there is a need to separate the relations between environmental variables, such as global geographical climate (average, minimum, and maximum temperature), population, and COVID-19 cases and death in humans. We, therefore, proposed to investigate the following:
- global geographical climate impacts on the COVID-19 spread and death in Asia

- global geographical climate impacts on the COVID-19 spread and death in America

- most important factors leading to COVID-19 spread and death in Asia and America

The employment of ANN is expected to contribute in understanding the impacts of global geographical climate towards COVID-19 spread and death. The arrangement of the remainder of this paper is as follows: the data background is explained in Section 2. The methods, including a description of the methodology and ANN structures, are covered in Section 3. In Section 4, our results and discussions are described. Finally, we present our conclusion in Section 5 .

\subsection{Data background}

The easiest way to format your manuscript is to A COVID-19 dataset for Asia and America that includes the number of cases and deaths from the European Centre for Disease Prevention and Control (ECDPC), global regional climate data from the Weather Forecast, and demographic data from the Current World Population America during April 2020 were compiled.

Forty one countries in Asia and 49 states in America were covered by the dataset. However, three countries, Palestine, Tajikistan and Yemen, were removed from Asia as a result of incomplete data distribution. The data from descriptive statistics for Asia and America can be referred in Table 1 and Table 2 distinctly.

Table 1 Descriptive statistics of Asia

\begin{tabular}{|c|c|c|c|c|c|c|c|c|c|c|c|}
\hline & & Cases & Deaths & $\begin{array}{l}\text { High } \\
\text { Temp } \\
\left({ }^{0} \mathbf{F}\right)\end{array}$ & $\begin{array}{l}\text { Low } \\
\text { Temp } \\
\left({ }^{\circ} \mathbf{F}\right)\end{array}$ & $\begin{array}{l}\text { Average } \\
\text { Temp }\left({ }^{\circ} \mathbf{F}\right)\end{array}$ & Population & $\begin{array}{l}\text { Total } \\
\text { Cases }\end{array}$ & $\begin{array}{l}\text { Total } \\
\text { Death }\end{array}$ & $\begin{array}{l}\text { Percent } \\
\text { Cases/ } \\
\text { Population }\end{array}$ & $\begin{array}{l}\text { Percent } \\
\text { Death/ } \\
\text { Population }\end{array}$ \\
\hline \multirow[t]{2}{*}{$\mathrm{N}$} & Valid & 38 & 38 & 38 & 38 & 38 & 38 & 38 & 38 & 38 & 38 \\
\hline & $\begin{array}{l}\text { Missin } \\
\mathrm{g}\end{array}$ & 3 & 3 & 3 & 3 & 3 & 3 & 3 & 3 & 3 & 3 \\
\hline \multicolumn{2}{|c|}{ Mean } & $\begin{array}{l}303.853 \\
7\end{array}$ & 8.5366 & 81.7756 & 63.9220 & 72.8756 & $\begin{array}{l}111331860.0 \\
732\end{array}$ & $\begin{array}{l}11519.7 \\
805\end{array}$ & 363.8293 & .0094 & .0002 \\
\hline \multicolumn{2}{|c|}{ Median } & 32.0000 & .0000 & 88.7000 & 69.1000 & 79.3000 & $\begin{array}{l}23816775.00 \\
00\end{array}$ & $\begin{array}{l}6991.00 \\
00\end{array}$ & 165.0000 & .0000 & .0000 \\
\hline \multicolumn{2}{|c|}{ Mode } & .00 & .00 & $66.20^{\mathrm{a}}$ & 77.00 & $83.60^{\mathrm{a}}$ & $437479.00^{\mathrm{a}}$ & $\begin{array}{l}4651.00 \\
\mathrm{a}\end{array}$ & $129.00^{\mathrm{a}}$ & .00 & .00 \\
\hline \multicolumn{2}{|c|}{ Std. Deviation } & $\begin{array}{l}579.743 \\
93\end{array}$ & 21.18620 & $\begin{array}{l}13.8301 \\
4\end{array}$ & $\begin{array}{l}14.1155 \\
7\end{array}$ & 13.39953 & $\begin{array}{l}303784756.3 \\
0899\end{array}$ & $\begin{array}{l}30617.9 \\
0898\end{array}$ & $\begin{array}{l}1238.190 \\
98\end{array}$ & .05739 & .00151 \\
\hline \multicolumn{2}{|c|}{ Variance } & $\begin{array}{l}336103 . \\
028\end{array}$ & 448.855 & 191.273 & 199.249 & 179.547 & $\begin{array}{l}9228517816 \\
5714976.000\end{array}$ & $\begin{array}{l}937456 \\
350.326\end{array}$ & $\begin{array}{l}1533116 . \\
895\end{array}$ & .003 & .000 \\
\hline \multicolumn{2}{|c|}{ Skewness } & 3.010 & 2.989 & -.785 & -.836 & -.751 & 4.090 & 6.376 & 6.388 & 6.376 & 6.366 \\
\hline
\end{tabular}


International Journal of Advanced Technology and Engineering Exploration, Vol 8(74)

\begin{tabular}{|c|c|c|c|c|c|c|c|c|c|c|c|}
\hline & & Cases & Deaths & $\begin{array}{l}\text { High } \\
\text { Temp } \\
\left({ }^{\circ} \mathbf{F}\right)\end{array}$ & $\begin{array}{l}\text { Low } \\
\text { Temp } \\
\left({ }^{\circ} \mathbf{F}\right)\end{array}$ & $\begin{array}{l}\text { Average } \\
\text { Temp }\left({ }^{\circ} \mathbf{F}\right)\end{array}$ & Population & $\begin{array}{l}\text { Total } \\
\text { Cases }\end{array}$ & $\begin{array}{l}\text { Total } \\
\text { Death }\end{array}$ & $\begin{array}{l}\text { Percent } \\
\text { Cases/ } \\
\text { Population }\end{array}$ & $\begin{array}{l}\text { Percent } \\
\text { Death/ } \\
\text { Population }\end{array}$ \\
\hline $\begin{array}{l}\text { Std. Er } \\
\text { Skewnes }\end{array}$ & $\begin{array}{ll}\text { rror of } \\
\text { ss }\end{array}$ & .369 & .369 & .369 & .369 & .369 & .369 & .369 & .369 & .369 & .369 \\
\hline Kurtosis & & 10.588 & 8.308 & -.341 & -.134 & -.433 & 16.218 & 40.762 & 40.869 & 40.757 & 40.666 \\
\hline $\begin{array}{l}\text { Std. Er } \\
\text { Kurtosis }\end{array}$ & rror of & .724 & .724 & .724 & .724 & .724 & .724 & .724 & .724 & .724 & .724 \\
\hline Range & & 2936.00 & 89.00 & 52.70 & 56.10 & 52.00 & $\begin{array}{l}1438886297 . \\
00\end{array}$ & $\begin{array}{l}199544 . \\
00\end{array}$ & 8032.00 & .37 & .01 \\
\hline Minimun & & .00 & .00 & 49.00 & 24.30 & 36.90 & 437479.00 & 2986.00 & 61.00 & .00 & .00 \\
\hline Maximur & & 2936.00 & 89.00 & 101.70 & 80.40 & 88.90 & $\begin{array}{l}1439323776 . \\
00\end{array}$ & $\begin{array}{l}202530 . \\
00\end{array}$ & 8093.00 & .37 & .01 \\
\hline Sum & & $\begin{array}{l}12458.0 \\
0\end{array}$ & 350.00 & 3352.80 & 2620.80 & 2987.90 & $\begin{array}{l}4564606263 . \\
00\end{array}$ & $\begin{array}{l}472311 . \\
00\end{array}$ & 14917.00 & .39 & .01 \\
\hline \multirow[t]{3}{*}{$\begin{array}{l}\text { Percent } \\
\text { iles }\end{array}$} & 25 & 1.0000 & .0000 & 72.1500 & 51.1000 & 60.6500 & $\begin{array}{l}5478484.000 \\
0\end{array}$ & $\begin{array}{l}5745.00 \\
00\end{array}$ & 135.5000 & .0000 & .0000 \\
\hline & 50 & 32.0000 & .0000 & 88.7000 & 69.1000 & 79.3000 & $\begin{array}{l}23816775.00 \\
00\end{array}$ & $\begin{array}{l}6991.00 \\
00\end{array}$ & 165.0000 & .0000 & .0000 \\
\hline & 75 & $\begin{array}{l}280.000 \\
0\end{array}$ & 4.5000 & 92.8500 & 76.0000 & 84.1000 & $\begin{array}{l}76896463.50 \\
00\end{array}$ & $\begin{array}{l}8344.50 \\
00\end{array}$ & 187.0000 & .0000 & .0000 \\
\hline
\end{tabular}

Table 2 Descriptive statistics of America

\begin{tabular}{|c|c|c|c|c|c|c|c|c|c|c|}
\hline & Cases & Deaths & $\begin{array}{l}\text { High } \\
\text { Temp } \\
\left({ }^{\circ} \mathbf{F}\right)\end{array}$ & $\begin{array}{l}\text { Low } \\
\text { Temp } \\
\left({ }^{\circ} \mathbf{F}\right)\end{array}$ & $\begin{array}{l}\text { Average } \\
\text { Temp }\left({ }^{\circ} \mathbf{F}\right)\end{array}$ & Population & $\begin{array}{l}\text { Total } \\
\text { Cases }\end{array}$ & $\begin{array}{l}\text { Total } \\
\text { Death }\end{array}$ & $\begin{array}{l}\text { Percent } \\
\text { Cases/ } \\
\text { Population }\end{array}$ & $\begin{array}{l}\text { Percent } \\
\text { Death/ } \\
\text { Population }\end{array}$ \\
\hline Valid & 49 & 49 & 49 & 49 & 49 & 49 & 49 & 49 & 49 & 49 \\
\hline Missing & 0 & 0 & 0 & 0 & 0 & 0 & 0 & 0 & 0 & 0 \\
\hline Mean & $\begin{array}{l}836.85 \\
71\end{array}$ & 71.5510 & 79.0918 & 64.3653 & 71.7408 & $\begin{array}{l}20850174.89 \\
80\end{array}$ & $\begin{array}{l}22548.2 \\
245\end{array}$ & $\begin{array}{l}1447.04 \\
08\end{array}$ & .0449 & .0031 \\
\hline $\begin{array}{l}\text { Std. Error of } \\
\text { Mean }\end{array}$ & $\begin{array}{l}569.75 \\
076\end{array}$ & 53.85549 & 2.01773 & 2.18519 & 2.04785 & $\begin{array}{l}8243724.115 \\
94\end{array}$ & $\begin{array}{l}17865.7 \\
9688\end{array}$ & $\begin{array}{l}1180.74 \\
562\end{array}$ & .01048 & .00106 \\
\hline Median & $2.4000^{\mathrm{a}}$ & $.4167^{\mathrm{a}}$ & $84.0667^{\mathrm{a}}$ & 71.5000 & $78.0000^{\mathrm{a}}$ & $\begin{array}{l}1399488.000 \\
0^{\mathrm{a}}\end{array}$ & 70.0000 & $6.1429^{\mathrm{a}}$ & $.0121^{\mathrm{a}}$ & $.0005^{\mathrm{a}}$ \\
\hline $\begin{array}{l}\text { Mode } \\
\text { Std Deviation }\end{array}$ & .00 & .00 & 86.00 & 71.60 & $78.80^{\mathrm{d}}$ & $3480.00^{\mathrm{d}}$ & 7.00 & .00 & $.00^{\mathrm{d}}$ & .00 \\
\hline Std. Deviation & $\begin{array}{l}3988.2 \\
5534 \\
\end{array}$ & $\begin{array}{l}376.9884 \\
5\end{array}$ & $\begin{array}{l}14.1241 \\
1\end{array}$ & $\begin{array}{l}15.2963 \\
3\end{array}$ & 14.33498 & $\begin{array}{l}57706068.81 \\
157\end{array}$ & $\begin{array}{l}125060 . \\
57816\end{array}$ & $\begin{array}{l}8265.21 \\
937 \\
\end{array}$ & .07339 & .00741 \\
\hline Variance & $\begin{array}{l}159061 \\
80.625\end{array}$ & $\begin{array}{l}142120.2 \\
94\end{array}$ & 199.490 & 233.978 & 205.492 & $\begin{array}{l}3329990377 \\
686125.000\end{array}$ & $\begin{array}{l}156401 \\
48208.8 \\
44\end{array}$ & $\begin{array}{l}683138 \\
51.290 \\
\end{array}$ & .005 & .000 \\
\hline Skewness & 6.414 & 6.655 & -2.217 & -1.723 & -1.952 & 4.288 & 6.882 & 6.880 & 2.728 & 3.908 \\
\hline $\begin{array}{l}\text { Std. Error of } \\
\text { Skewness }\end{array}$ & .340 & .340 & .340 & .340 & .340 & .340 & .340 & .340 & .340 & .340 \\
\hline Kurtosis & 42.830 & 45.437 & 4.947 & 2.201 & 3.185 & 19.684 & 47.838 & 47.808 & 8.669 & 16.064 \\
\hline $\begin{array}{l}\text { Std. Error of } \\
\text { Kurtosis }\end{array}$ & .668 & .668 & .668 & .668 & .668 & .668 & .668 & .668 & .668 & .668 \\
\hline Range & $\begin{array}{l}27326 . \\
00\end{array}$ & 2611.00 & 65.90 & 59.00 & 58.30 & $\begin{array}{l}330999171.0 \\
0\end{array}$ & $\begin{array}{l}875288 . \\
00\end{array}$ & $\begin{array}{l}57796.0 \\
0\end{array}$ & .37 & .04 \\
\hline Minimum & .00 & .00 & 29.80 & 19.40 & 25.30 & 3480.00 & 1.00 & .00 & .00 & .00 \\
\hline Maximum & $\begin{array}{l}27326 . \\
00\end{array}$ & 2611.00 & 95.70 & 78.40 & 83.60 & $\begin{array}{l}331002651.0 \\
0\end{array}$ & $\begin{array}{l}875289 . \\
00\end{array}$ & $\begin{array}{l}57796.0 \\
0\end{array}$ & .37 & .04 \\
\hline Sum & $\begin{array}{l}41006 . \\
00\end{array}$ & 3506.00 & 3875.50 & 3153.90 & 3515.30 & $\begin{array}{l}1021658570 . \\
00\end{array}$ & $\begin{array}{l}110486 \\
3.00\end{array}$ & $\begin{array}{l}70905.0 \\
0\end{array}$ & 2.20 & .15 \\
\hline $\begin{array}{l}\text { Percenti } 25 \\
\text { les }\end{array}$ & $.2500^{\mathrm{b}}$ & $. \mathrm{b}, \mathrm{c}$ & $76.6750^{\mathrm{b}}$ & 62.0000 & $69.0750^{\mathrm{b}}$ & $91443.2500^{\mathrm{b}}$ & 10.7500 & $.9643^{\mathrm{b}}$ & $.0061^{\mathrm{b}}$ & $.0000^{\mathrm{b}}$ \\
\hline $\begin{array}{l}\text { Percenti } \\
\text { les }\end{array}$ & 2.4000 & .4167 & 84.0667 & 71.5000 & 78.0000 & $\begin{array}{l}1399488.000 \\
0\end{array}$ & 70.0000 & 6.1429 & .0121 & .0005 \\
\hline 75 & $\begin{array}{l}45.000 \\
0\end{array}$ & 2.5000 & 86.5727 & 73.6917 & 80.0333 & $\begin{array}{l}11470151.25 \\
00\end{array}$ & $\begin{array}{l}1268.50 \\
00\end{array}$ & 68.0000 & .0484 & .0028 \\
\hline
\end{tabular}




\section{Research methods}

The Artificial Neural Network of Multilayer Perceptron (ANN-MLP) model was chosen in this analysis. ANN was carried out using SPSS 23. In [16-19], a similar approach can be seen. With the hyperbolic tangent transfer function in the first layer and the purelin transfer function in the second layer, the two-layer neural network is adapted. The training function used in this research is Trainscg, with a mean square error (MSE) equivalent to 0.0 as the criterion function. The theoretical structure consists of two variables, as seen in Table 3, which are independent and dependent variables. Meanwhile, Figure 1 indicates the theoretical structure of this study.

The neural network model with nine predictor variables for Asia and America are represented in Equation (1) and Equation (2).

\begin{tabular}{|l|l|l|}
\hline Independent Variables & \multicolumn{2}{|l|}{} \\
\hline X1: Daily Cases & & \\
X2: Daily Death & & \\
X3: High Temperature & & \\
X4: Low Temperature & & \\
X5: Population & \\
X6: \% Cases over Population & \\
X7: \% Death over Population & \\
X8: Average Temperature & \\
X9: Total Cases & \\
\hline
\end{tabular}

Figure 1 Theoretical structures

Table 3 Descriptive type of variables

\begin{tabular}{llll}
\hline Variable & Description & Notation & Type \\
\hline Dependent & Total Death & TOTAL DEATH & Continuous \\
\hline & Daily Cases & cases & Continuous \\
\cline { 2 - 4 } & Daily Death & death & Continuous \\
\cline { 2 - 4 } & High Temperature & HIGH TEMPERATURE & Continuous \\
\cline { 2 - 4 } & Low Temperature & LOW TEMPERATURE & Continuous \\
\cline { 2 - 4 } & Population & population & Continuous \\
\cline { 2 - 4 } & $\%$ Cases over Population & PERCENT CASES & Continuous \\
\cline { 2 - 3 } & & POPULATION & Continuous \\
\hline
\end{tabular}

$Y=\operatorname{purelin}\left[L W^{2,1}\left[\tanh \left\{\begin{array}{l}\left(I W_{1}\right)^{1,1} * X 1+ \\ \left(I W_{2}\right)^{1,2} * X 2+ \\ \left(I W_{3}\right)^{1,3} * X 3+ \\ \left(I W_{4}\right)^{1,4} * X 4+ \\ \left(I W_{5}\right)^{1,5} * X+ \\ \left(I W_{6}\right)^{1,6} * X 6+ \\ \left(I W_{7}\right)^{1,7} * X 7+ \\ \left(I W_{8}\right)^{1,8} * X 8+ \\ \left(I W_{9}\right)^{1,9} * X 9\end{array}\right]\right)\right]$ 


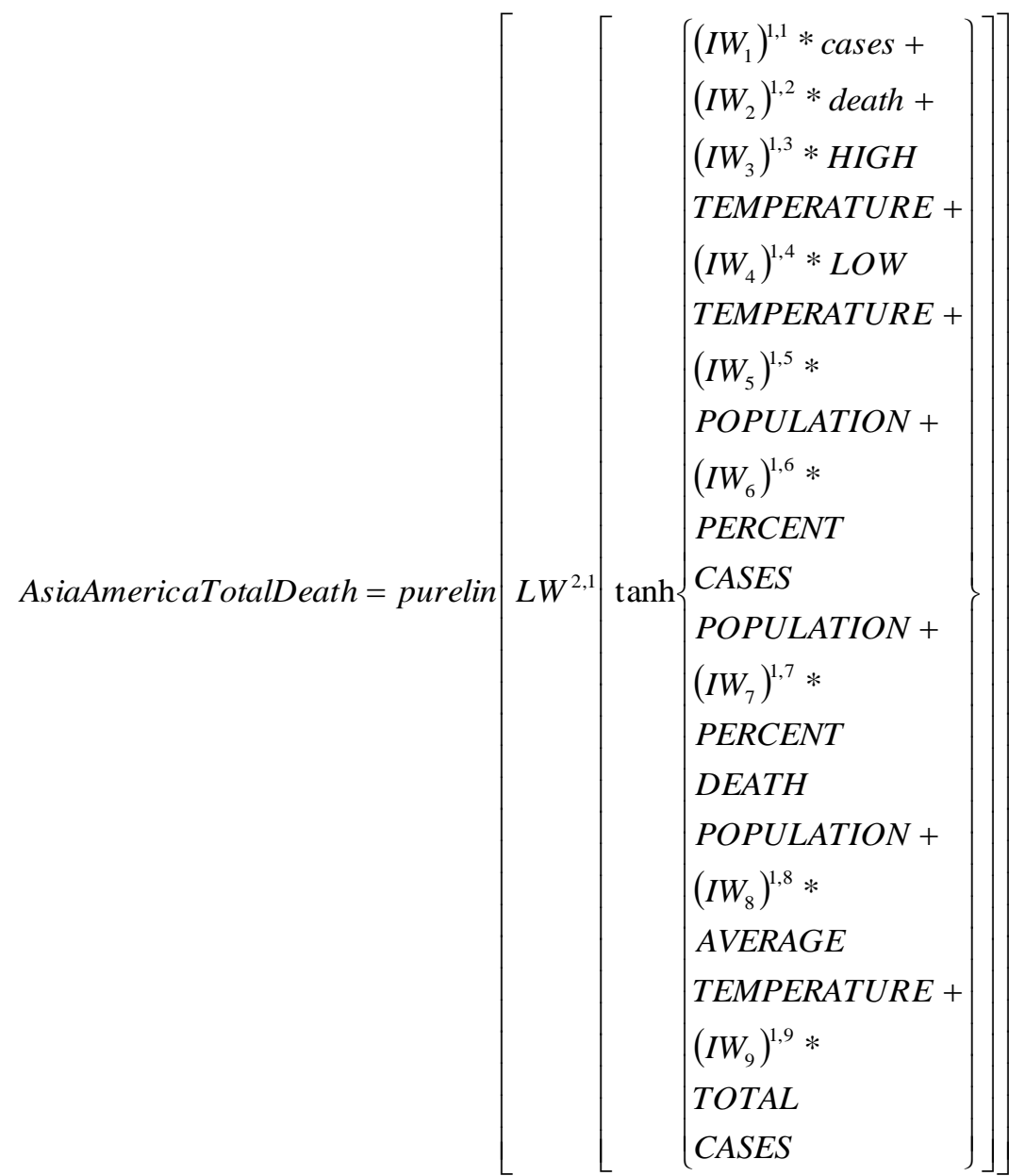

The Cases, Death, High Temperature, Low Temperature, Population, Percentage of Cases over Population, Percentage of Death over Population, Average Temperature, and Total Cases were the covariates of the network. These nine covariates were the input nodes of the network's input layer. These networks consist of one hidden layer with a single node for both Asia and America. The hyperbolic tangent was an activation function from the input layer to the hidden layer. The target of the network is
COVID-19 spread and death, where the activation function from hidden layer to output layer was identity (purelin). The default error function in back propagation neural network was based on Sum of Square Error (SSE). The configurations of these networks were 9-1-1, to simplify. Figure 2 and Figure 3 display the architecture of the networks. Next, the overall network information for Asia and America are tabulated in Table 4.

Table 4 Network information - Asia and America

\begin{tabular}{|c|c|c|c|}
\hline \multirow[t]{11}{*}{ Input Layer } & \multirow{9}{*}{ Covariates } & 1 & Cases \\
\hline & & 2 & Death \\
\hline & & 3 & High Temperature \\
\hline & & 4 & Low Temperature \\
\hline & & 5 & Population \\
\hline & & 6 & $\%$ Cases over Population \\
\hline & & 7 & \% Death over Population \\
\hline & & 8 & Average Temperature \\
\hline & & 9 & Total Cases \\
\hline & Number of Units ${ }^{\mathrm{a}}$ & & 9 \\
\hline & Rescaling Method for Covariates & & Standardized \\
\hline Hidden Layer(s) & Number of Hidden Layers & & 1 \\
\hline
\end{tabular}


Shafaf Ibrahim et al.

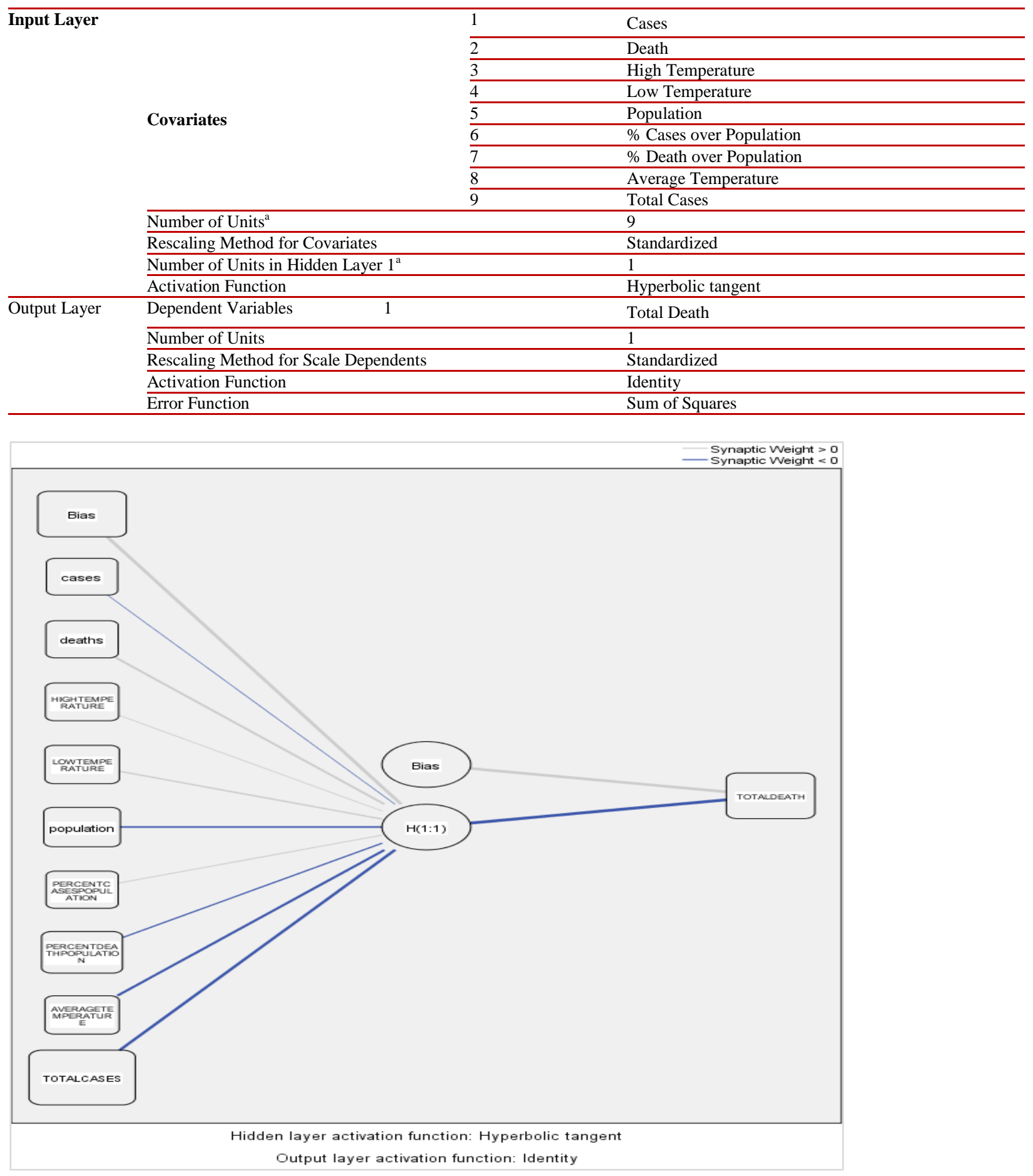

Figure 2 Network architecture - Asia 


\section{Results}

Table 5 and Table 6 show the case processing summary for Asia and America. Based on the tables, the data was split into two parts in the preprocessing section; training and testing. The training set consists of $73.17 \%$ (30/41) of the total data, while the test set consists of $19.5 \%(8 / 41)$ of the total data, $\mathrm{N}=41$. Three excluded data were recorded. The training set consists of $77.6 \%(38 / 49)$ of the overall data for America, while the test sets consist of $22.4 \%$ (11/49) of the overall data, $N=49$. No excluded data has been registered.

Table 7 and Table 8 depict the model summary for Asia and America accordingly. For Asia, the SSE for training set was 0.045, with Relative Error (RE) equals to 0.003 . On the other hand, the SSE for testing sets was 0.036, with RE equals to 9.527 .

Table 5 Case processing summary - Asia

\begin{tabular}{llll}
\hline & & $\mathbf{N}$ & Percent \\
\hline Sample & Training & 30 & $73.17 \%$ \\
\cline { 2 - 4 } & Testing & 8 & $19.51 \%$ \\
\hline Valid & & 38 & $92.68 \%$ \\
\hline Excluded & 3 & \\
\hline Total & 41 & \\
\hline
\end{tabular}

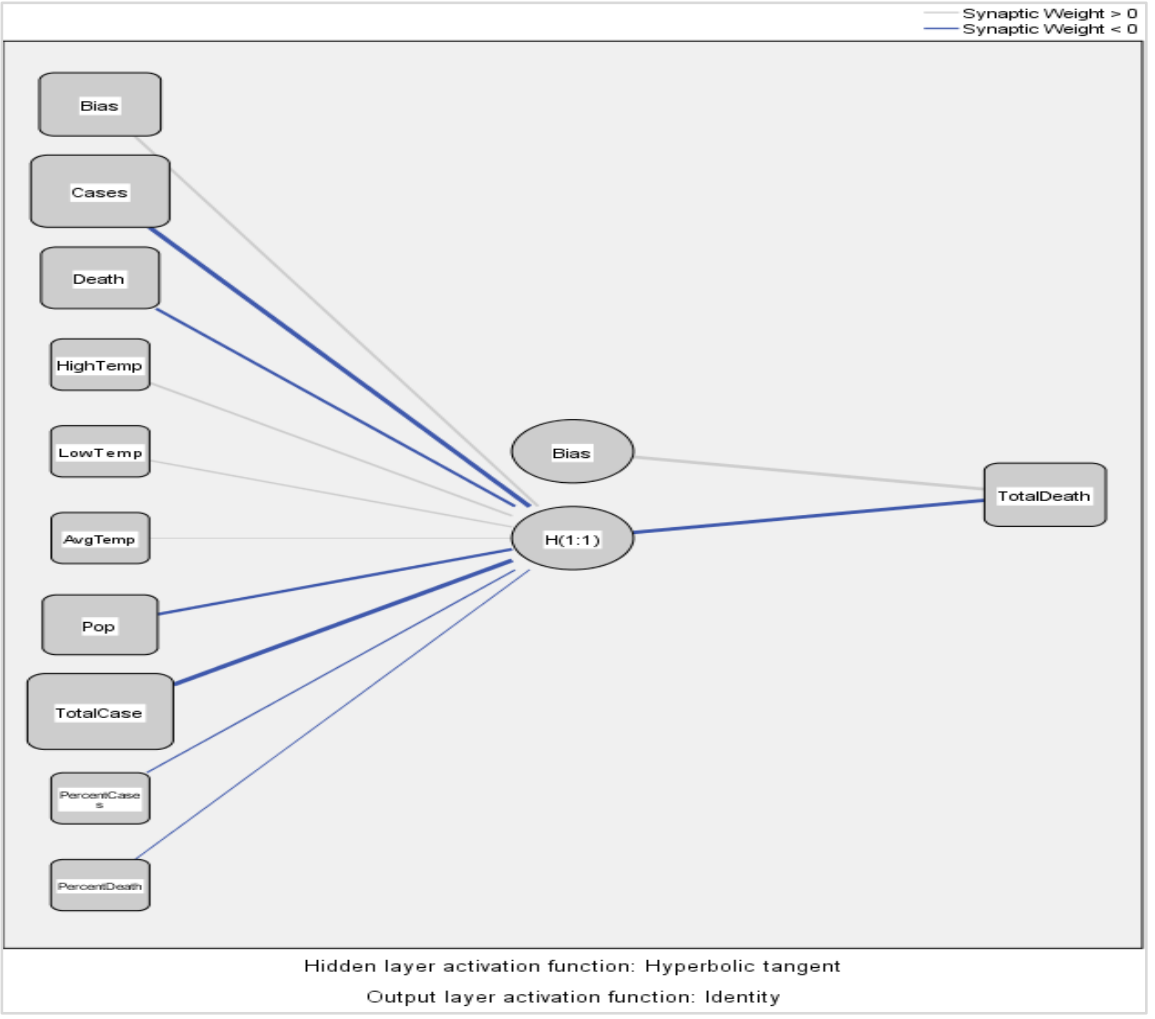

Figure 3 Network architecture - America

Table 6 Case processing summary - America

\begin{tabular}{llll}
\hline Sample & N & Percent \\
& Training & 38 & $77.6 \%$ \\
\cline { 2 - 4 } & Testing & 11 & $22.4 \%$ \\
\hline Valid & 49 & $100.0 \%$ \\
\hline Excluded & 0 & \\
\hline Total & 49 & \\
\hline
\end{tabular}


Shafaf Ibrahim et al.

Table 7 Model summary - Asia

\begin{tabular}{lll}
\hline \multirow{2}{*}{ Training } & Sum of Squares Error & .045 \\
\cline { 2 - 3 } & Relative Error & .003 \\
\hline \multirow{2}{*}{ Testing } & Stopping Rule Used & 1 consecutive step(s) with no decrease in error \\
& Sum of Squares Error & .036 \\
\cline { 2 - 3 } Dependent Variable: & TOTALDEATH & 9.527 \\
\hline
\end{tabular}

Alternatively, for the training sets, America is observed to record 0.026 of SSE and 0.02 of RE. In testing, 0.012 of SE and 0.472 of RE were returned. It can be said that in any network, testing set should be the reference. The RE was 9.527 and 0.757 for both Asia and America, which were quite low. The efficiency of the network is therefore assumed to be in a decent structure.
The independent variable importance reflects the significance of networks' model-predicted value with the independent variable's different values. The normalized importance is essentially the percentages of importance divided by the largest importance values. Table 9 and Table 10 portray the independent variable importance for Asia and America.

Table 8 Model summary-America

\begin{tabular}{lll}
\hline \multirow{2}{*}{ Training } & Sum of Squares Error & .026 \\
\cline { 2 - 3 } & Relative Error & .002 \\
\cline { 2 - 3 } Testing & Stopping Rule Used & .012 \\
\hline Dependent Variable: & TOTALDEATHe step(s) with no decrease in error & \\
\cline { 2 - 3 } & Relative Error & .757 \\
\hline
\end{tabular}

Table 9 Independent variable importance - Asia

\begin{tabular}{lll}
\hline & Importance & Normalized importance \\
\hline Cases & 0.006 & $1.0 \%$ \\
\hline Deaths & 0.021 & $3.8 \%$ \\
\hline High Temperature & 0.039 & $7.0 \%$ \\
\hline Low Temperature & 0.056 & $10.1 \%$ \\
\hline Population & 0.090 & $16.1 \%$ \\
\hline$\%$ Cases over Population & 0.019 & $3.5 \%$ \\
\hline \% Death over Population & 0.157 & $28.2 \%$ \\
\hline Average Temperature & 0.054 & $9.8 \%$ \\
\hline Total Cases & 0.558 & $100.0 \%$ \\
\hline
\end{tabular}

Table 10 Independent variable importance-America

\begin{tabular}{|c|c|c|}
\hline & Importance & Normalized importance \\
\hline Cases & .307 & $85.2 \%$ \\
\hline Death & .155 & $43.0 \%$ \\
\hline High Temperature & .011 & $2.9 \%$ \\
\hline Low Temperature & .010 & $2.9 \%$ \\
\hline Average Temperature & .006 & $1.6 \%$ \\
\hline Population & .133 & $37.0 \%$ \\
\hline Total Cases & .360 & $100.0 \%$ \\
\hline$\%$ Cases over Population & .009 & $2.5 \%$ \\
\hline$\%$ Death over Population & .010 & $2.7 \%$ \\
\hline
\end{tabular}




\section{Discussions}

Referring to the percentages of normalized importance in Table 9 and Table 10, the Total Cases $(100 \%)$, Percentage of Death over Population $(28.2 \%)$ and Population $(16.1 \%)$ are the three most important factors leading to COVID-19 spread and death in Asia. Contrastively, the three most important variables that lead to COVID-19 spread and death in America are Total Cases (100\%), Cases (85.2\%) and
Death (43\%). The global geographical climate defined by High Temperature, Low Temperature, and Average Temperature appear to have a minimum impact on the COVID-19 spread and death in Asia and America as it returned low percentages of normalized importance in both Asia and America in the range of 1.6\%-10.1\% only. Figure 4 and Figure 5 display the corresponding figures.

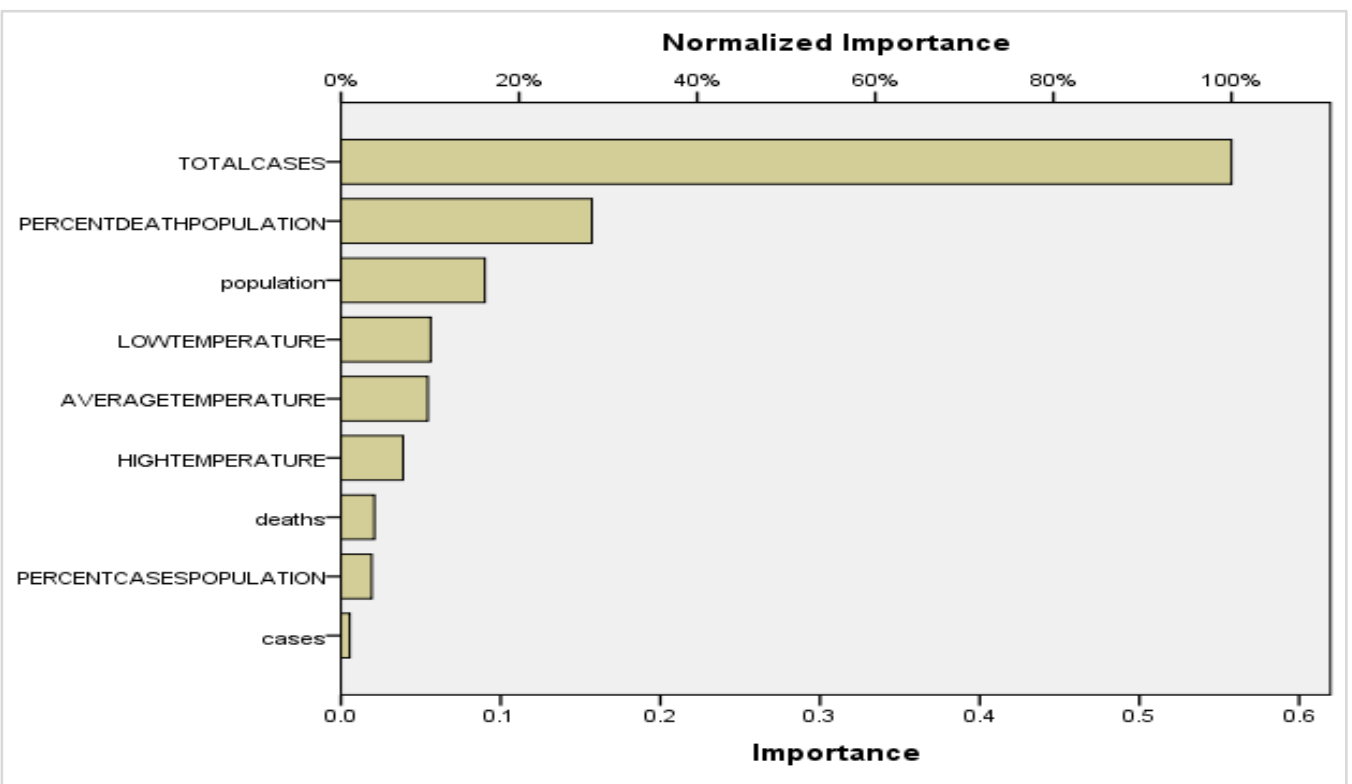

Figure 4 Normalized importance -Asia

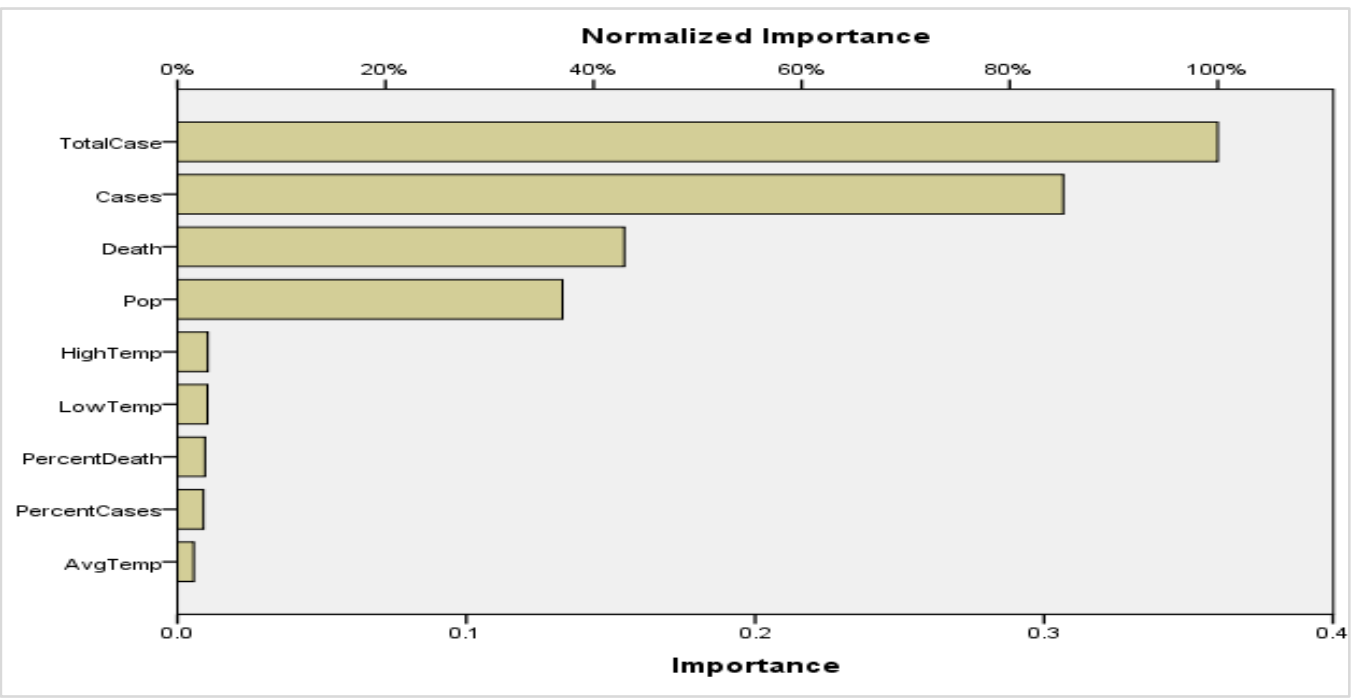

Figure 5 Normalized importance - America 
In view of the minimum impacts of geographical global climate on the COVID-19 spread and death in Asia and America, the correlation graphs of Average Temperature and Total Cases, and Average Temperature and Total Deaths are then constructed in Figure 6 and Figure 7.

Based on the correlation analysis in Figure 6 and Figure 7, it is monitored that the COVID-19 cases and death has negative association with climate as the total number of cases and death are unpredictably distributed along the Average Temperature. Small number of cases and death could be monitored in the high temperature countries, as well as the low temperature countries. The findings of the study are summarized as below:

- The three most important factors leading to COVID-19 spread and death in Asia are: total cases, percentage of death over population, and population.

- The three most important factors leading to COVID-19 spread and death in America are: total cases, cases, and death.

- Global geographical climate which represented by High Temperature, Low Temperature, and Average Temperature appear to have a minimum impact on the COVID-19 spread and death in both Asia and America.

It can therefore be inferred that the global geographic climate has the least impacts on the COVID-19 spread and death in Asia and America. Nevertheless, an investigation on the global geographical climate impacts on the COVID-19 spread and death at different continentals could summarize the findings in future.

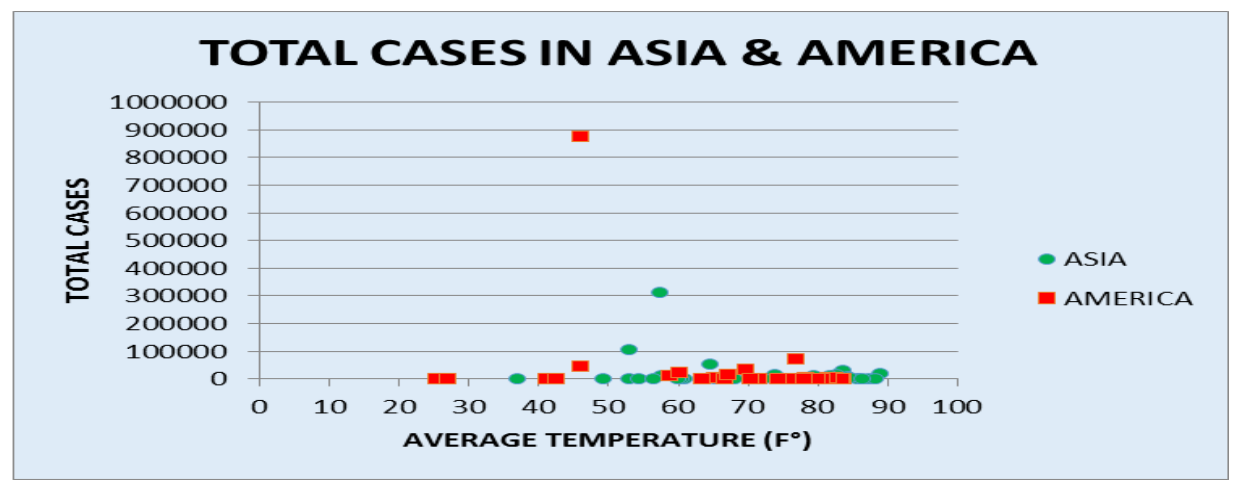

Figure 6 Correlation Graph of average temperature and total cases in Asia and America

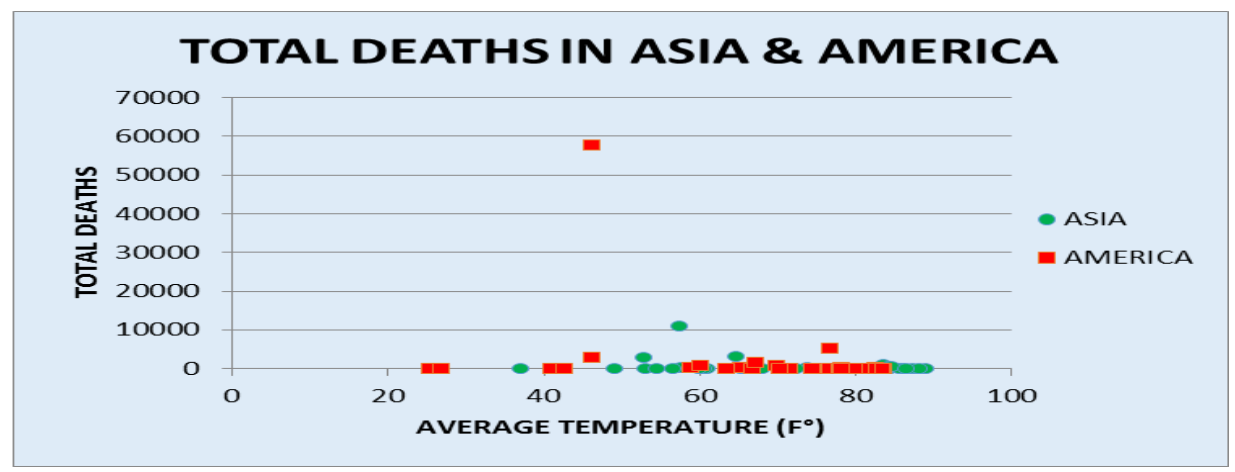

Figure 7 Correlation graph of average temperature and total death in Asia and America

\section{Conclusion and future work}

This paper presents a study on the impacts of global geographic climate towards the COVID-19 spread and death in Asia and America. The objective of this paper has been successfully achieved. The Artificial Neural Network of Multilayer Perceptron (ANNMLP) model was implemented. The configuration of 158 the networks adapted were 9-1-1 for both Asia and America, with hyperbolic tangent and purelin activation functions in hidden layer and output layer respectively. Nine covariates were set for each Asia and America. The Total Cases, Cases, Death, Percentage of Death over Population, and Population were observed to contribute to the major effects of 
COVID-19 spread and death in Asia and America. On the other hand, temperatures appear to give small impacts on the spread and death. Thus, it can be concluded that the global geographic climate has the least impacts on the COVID-19 spread and death in Asia and America particularly. A lot of studies on COVID-19 spread and death at different world continental could be done in which the impacts of the global geographical climate could be seen comprehensively in future. An implementation and incorporation of the current prediction and analysis techniques are also suggested.

\section{Acknowledgment}

None

\section{Conflicts of interest}

The authors have no conflicts of interest to declare.

\section{References}

[1] Florindo HF, Kleiner R, Vaskovich-Koubi D, Acúrcio RC, Carreira B, Yeini E, et al. Immune-mediated approaches against COVID-19. Nature Nanotechnology. 2020; 15:630-45.

[2] Klein SL, Dhakal S, Ursin RL, Deshpande S, Sandberg K, Mauvais-Jarvis F. Biological sex impacts COVID-19 outcomes. PLoS Pathogens. 2020; 16(6):15.

[3] World Health Organization. Coronavirus Disease (COVID-19). 2020.

[4] Chan KH, Peiris JM, Lam SY, Poon LL, Yuen KY, Seto WH. The effects of temperature and relative humidity on the viability of the SARS coronavirus. Advances in Virology. 2011.

[5] Lin K, Fong DY, Zhu B, Karlberg J. Environmental factors on the SARS epidemic: air temperature, passage of time and multiplicative effect of hospital infection. Epidemiology \& Infection. 2006; 134(2):223-30.

[6] Sobral MF, Duarte GB, Da Penha Sobral AI, Marinho ML, De Souza Melo A. Association between climate variables and global transmission oF SARS-CoV-2. Science of The Total Environment. 2020; 729.

[7] Bao J, Wang Z, Yu C, Li X. The influence of temperature on mortality and its lag effect: a study in four Chinese cities with different latitudes. BMC Public Health. 2016; 16:1-8.

[8] Park JE, Son WS, Ryu Y, Choi SB, Kwon O, Ahn I. Effects of temperature, humidity, and diurnal temperature range on influenza incidence in a temperate region. Influenza and Other Respiratory Viruses. 2020; 14(1):11-8.

[9] Oliveiros B, Caramelo L, Ferreira NC, Caramelo F. Role of temperature and humidity in the modulation of the doubling time of COVID-19 cases. medRxiv. 2020.

[10] Ansari A, Heras M, Nones J, Mohammadpoor M, Torabi F. Predicting the performance of steam assisted gravity drainage (SAGD) method utilizing artificial neural network (ANN). Petroleum. 2020; 6(4):368-74.

[11] Zhang Y, Pan G, Chen B, Han J, Zhao Y, Zhang C. Short-term wind speed prediction model based on GAANN improved by VMD. Renewable Energy. 2020; 156:1373-88.

[12] Hamoud A, Humadi A. Student's success prediction model based on artificial neural networks (ANN) and a combination of feature selection methods. Journal of Southwest Jiaotong University. 2019; 54(3):1-19.

[13] Chen RP, Zhang P, Kang X, Zhong ZQ, Liu Y, Wu HN. Prediction of maximum surface settlement caused by earth pressure balance (EPB) shield tunneling with ANN methods. Soils and Foundations. 2019; 59(2):284-95.

[14] Ghimire S, Deo RC, Downs NJ, Raj N. Global solar radiation prediction by $\mathrm{ANN}$ integrated with European centre for medium range weather forecast fields in solar rich cities of Queensland Australia. Journal of Cleaner Production. 2019; 216:288-310.

[15] Ibrahim S, Kamaruddin SA, Mangshor NN, Fadzil AF. Performance evaluation of multi-layer perceptron (MLP) and radial basis function (RBF): COVID-19 spread and death contributing factors. International Journal of Advanced Trends in Computer Science and Engineering. 2020; 9(1.4):625-31.

[16] Yin M, Ma J, Xu J, Li L, Chen G, Sun Z, et al. Use of artificial neural networks to identify the predictive factors of extracorporeal shock wave therapy treating patients with chronic plantar fasciitis. Scientific Reports. 2019; 9(1):1-8.

[17] Zhang K, Hu Y, Wu Y. Classification and prediction on rural property mortgage data with three data mining methods. Journal of Software Engineering and Applications. 2018; 11(07):348-61.

[18] Ibrahim S, Kamaruddin SA, Sabri N, Samah KA, Noordin M, Shari A. The influences of global geographical climate towards COVID-19 spread and death. International Journal of Advanced Trends in Computer Science and Engineering. 2020.

[19] Mahmoud AS, Farag RS, Elshfai MM, Mohamed LA, Ragheb SM. Nano zero-valent aluminum (nZVAl) preparation, characterization, and application for the removal of soluble organic matter with artificial intelligence, isotherm study, and kinetic analysis. Air, Soil and Water Research. 2019; 12:1-13.

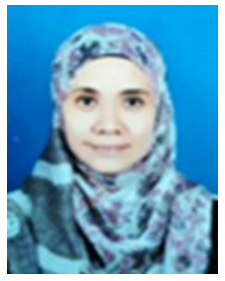

Shafaf Ibrahim is a Senior Lecturer in Faculty of Computer and Mathematical Sciences, Universiti Teknologi MARA (Malacca) Jasin Campus. Have a qualification of Diploma, Bachelor's Degree, Masters and $\mathrm{PhD}$ in Computer Science. Her research interests are Artificial Intelligence, Evolutionary Algorithms, Image Processing, and Optimization. Email: shafaf2429@uitm.edu.my 


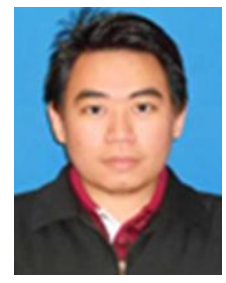

Saadi Ahmad Kamaruddin is a Senior Lecturer at School of Quantitative Sciences (SQS), Universiti Utara Malaysia (UUM). He was the National Champion in Electrical Engineering (Evolutionary Algorithm) in 2018. He received his Doctorate Degree from Universiti Teknologi MARA (UiTM) in 2018 as well.

Email: s.ahmad.kamaruddin@uum.edu.my

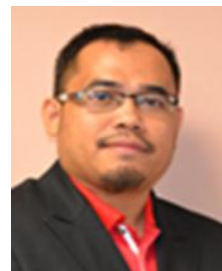

Mohd Rahmat Mohd Nordin currently is a Lecturer in Universiti Teknologi MARA (Melaka) Kampus Jasin in Merlimau, Malaysia. $\mathrm{He}$ received his Master (Hons.) of Software Engineering from Universiti Teknologi Malaysia (UTM), Malaysia.

Email: mrahmat.noordin@uitm.edu.my

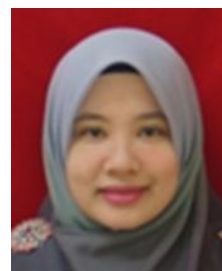

Anis Amilah Shari born in 1985 , currently is a Lecturer at Faculty of Computer and Mathematical Sciences, University Technology MARA (UiTM). She received her Master of Science from University Technology MARA (UiTM) Shah Alam in 2014.

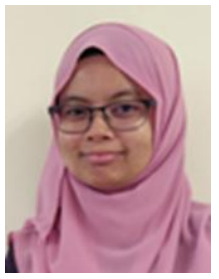

Nurbaity Sabri is a lecturer in University Technology MARA (UiTM) Melaka, Jasin branch. She holds a Master in Computer Science from Universiti Teknologi Malaysia (UTM). She is a programming lecturer and currently teaching computer programming in $\mathrm{C}++$ and Java

Programming.

Email: nurbaity_sabri@uitm.edu.my

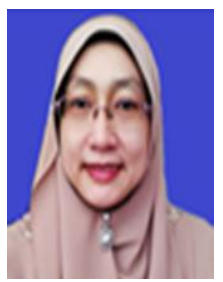

Khyrina Airin Fizah Abu Samah is a senior lecturer from Universiti Teknologi MARA (UiTM), Melaka Jasin Campus. She has 13 years of working experience in the Information Technology field in the semiconductor industry before joining UiTM. She has Diploma, Bachelor's Degree and Master's Degree in Computer Science and $\mathrm{PhD}$ in Information Technology. Her research interest in Artificial Intelligent, Operational Research, Algorithm Analysis, Clustering and Optimization, Evacuation Algorithm, Internet of Things (IoT) and Sentiment Analysis.

Email: khyrina783@uitm.edu.my

Email: anisamilah@uitm.edu.my 